VAK $347.97 / .99$

ББК 67.71

DOI 10.22394/1682-2358-2020-2-45-53

E.B. Ablaeva, Candidate of Sciences (Law), Docent of the Legal Disciplines Department, Astana University, Republic of Kazakbstan

\section{SPECIALIZATION \\ OF COURTS \\ AND JUDGES \\ IN KAZAKHSTAN}

The author traces a consistent path of development of the judicial system of the Republic of Kazakhstan, moving in the direction from the specialization of judges to the specialization of courts. Specialization of courts and judges is designated as the main vector of development of the judicial system and improvement of judicial proceedings in the Republic of Kazakhstan. The conducted research allowed us to conclude that the Kazakh model of the judicial system is built in accordance with the principle of judicial specialization.

Key words and word-combinations: judicial specialization, specialization of judges, specialization of courts, judicial reform, virtual courts, night courts.
Э.Б. АблаеВа, кандидат юридиеских наук, дочент кафедрь юридических дисииплин Университета «Астана», Республика Казахстан (email: Ablaeva_1981@mail.ru)

\section{СПЕЦИААИЗАЦИЯ СУАОВ И СУАЕЙ В КАЗАХСТАНЕ}

Аннотация. Прослеживается последовательное развитие судебной системы Республики Казахстан от специализации судей к специализации судов. Специализация судов и судей является основным вектором развития судоустройства и совершенствования судопроизводства РК. Сформулирован вывод о построении казахстанской модели судебной системы в соответствии с принципом судебной специализации.

Ключевые слова и словосочетания: судебная специализация, специализация судей, специализация судов, судебная реформа, виртуальные суды, ночные суды.

.T емпы изменения текущего законоАательства, - на верный взгляА известного казахстанского ученого К.А. Мами, - не ПОЗвОАяют СУАьям СУАОВ общей ЮрисАИКции охватить и применять новеммы по всем отраслям права» [1, с. 84]. Это одна из главных причин, вызвавших необходимость организации и устройства в Респубцике Казахстан специализированных судов.

СреАи Аругих причин реформирования судебной системы РК казахстанские авторы называют ряА обстоятельств. По мнению Г.Ж. Сулейменовой, в условиях рыночной экономики правоотношения в сфере эко- 
номической, банковской, финансовой, таможенной, страховой деятемьности усложнились; появицись новые категории дел, рассмотрение и разрешение которых требовало специацизаџии в соответствующих отраслях права [2, с. 74].

Развивая эту мысль, Р.Н. Юрченко пишет: «Количество и характер конфмиктных ситуаций в указанных сферах жизни и деятельности возрастал, соответственно характер дец об административных правоотношениях существенно изменился и их количество возросло» [3, с. 11].

В результате рассмотрения условий возникновения и развития специамизированных судов становится очевидным, что в постсоветском Казахстане Аостаточно широко распространен принџип спеџиализаџии судей и судов. А.А. Сабитова совершенно права в том, что принцип судебной специализации не является принџипиально новым Аля судебной системы современного Казахстана. Исследуя перспективы развития новых процессуальных форм судопроизводства, автор пишет, что судебная специализация существовала еще во времена соџиалистического Казахстана, подтверждением чему явцяются судьи по административному и исполнительному производству, которые в последующем создали почву Аля появления современных специализированных судов [4, с. 37-38].

Солидаризуясь с этим мнением, отметим, что развитие судебной системы и совершенствование судебной деятельности РК осушествляется поэтапно, в направлении от специализированных судей - к специализированным судам. Предметом изучения настоящей работы, связанной с обзором законодательства, Аействующего со дня провозглашения государственного суверенитета Республики Казахстан, является изложение основных шагов, проделанных государством Аля утверждения, соблюдения и развития принџипа судебной специализации.

Перьъй шаг. В Казахстане вопрос об организации устройства и функционирования судебной системы в соответствии с принџипом судебной специамизаџии впервые возник незадолго до распада Союза ССР. В хронике значимых событий дця постсоветского Казахстана явмяется принятие, как и рядом некоторых бывших союзных республик, Аекцарации о государственном суверенитете от 25 октября 1990 г. Аекларативным документом в прошлом Казахская ССР, а в настоящем Республика Казахстан провозгласила себя суверенным государством. Приобретение этого статуса создало не только предпосылки, но и положицо начало реформированию прежнего строя советской государственности, в проџессе которого кардинацьным изменениям подверглась и система органов правосудия. ВслеА за этим значимым событием, 23 ноября 1990 г., последовац Закон Казахской ССР о судоустройстве Казахской ССР, которым впервые быма введена судебная специализация по рассмотрению и разрешению дел, связанных с нарушением норм законодательства об административных правонарушениях и исполнением судебных актов.

Итак, Ао 2000-х годов при районных (городских) народных судах (народных судей) состояли суАьи по аАминистративному и исполнительному произ- 
водству. Основой правового регулирования организаџии и функщионирования судебной системы союзной республики явмялся Закон о судоустройстве Казахской ССР. В соответствии с его ст. 5 и ст. 33 судьи по административному и исполнительному производству наряду с народными судьями осуществмяли производство по делам об административных правонарушениях; по поручению председателя районного (городского) народного суда контролировали деятельность судебных исполнителей и мишь в указанных законом случаях обеспечивали исполнение судебных актов, вынесенных по гражданским делам [5, ст. 5; ст. 33]. Соответственно, появление в Казахстане первых специализированных судей следует отнести к началу 1990-х годов.

К сожалению, многие авторы возникновение и развитие в РК специализированных судов неверно относят к началу 2000-х годов и связывают их с Конџепцией правовой политики РК, утвержАенной на период 2002-2010 гг. Ошибочность такого мнения состоит еще и в том, что появление всех спещиализированных судов в РК связывается с процессом ее интеграции в мировое сообшество [6, с. 50]. Подобные часто встречаюшиеся ошибочные выводы Аелаются потому, что одни авторы не имеют преАставлений о модели построения судебной системы РК; вторые не изучили все правовые основы регулирования организаџии и функџионирования деятельности судебной системы РК; третьи глубоко не исследовали историю возникновения и развития специализированных судов.

Второй шаг. Утвержденная в 1994 г. постановлением первого Президента РК Государственная программа правовой реформы впервые опредецика специализаџию судей в качестве одной из приоритетных целей, Амя Аостижения которой проводится преобразование судебной системы. Аیя Аостижения поставленной цели на первых порах реформирования в высшем органе судебной власти, входящем в систему общих судов - Верховном Суде РК - предусматривалось создание спеџиализированных юридических комлегий, а в Аругих судах общей юрисдикџии предполагалось провести широкую и глубокую спеџиализаџию судей, в том числе и по спорам межАу хозяйствующими субъектами. В итоге в структуре Верховного Суда РК Ао вступцения в силу конституџионного закона РК о судебной системе и статусе судей функционировали четыре судебные комлегии: по гражданским делам, хозяйственным делам, уголовным делам и военная комлегия. Высший Арбитражный СуА РК действовал до организации устройства и функционирования специализированных судов.

В соответствии с Государственной программой правовой реформы новое уголовно-процессуальное законодательство должно обеспечивать соблюдение принципа состязательности уголовного процесса. Задачи, поставленные переА новым уголовным судопроизводством, стали почвой для зарождения законодательных иниџиатив о необходимости усицения судебного контроця, осуществмяемого за правицьным ходом досудебного уголовного производства на его более ранних стадиях.

Вторая Конституция РК от 1995 г. закрепила основные идеи, продиктованные Государственной программой правовой реформы от 1994 г. В частности, 
применение мер процессуального принуждения или пресечения, связанные с ограничением или мишением свободы, Аопустимы только с санкщии судьи, что и положило начало развитию и становлению в РК спещиализированных слеАственных суАей и суАов.

Третий шаг. В 1997 г. быма одобрена Стратегия развития «Казахстан2030». В ней поставлены три важные задачи: достижение экономического процветания; сохранение политической стабимьности и обеспечение социального благополучия.

Год спустя стали разрабатываться государственные программы борьбы с коррупцией, направленные на реализацию Аолгосрочных приоритетов, обозначенных в Стратегии развития «Казахстан-2030»: 1) внутриполитическая стабильность и консолидация общества и 2) профессионацьное правительство. В первой Авухлетней государственной программе, рассчитанной на 1999-2000 гг., укрепление правоохранительных и судебных систем видецось в развитии административной юстиции [7]. К сожалению, в послеАующих пятилетних государственных программах развитие административной юстиции в качестве меры борьбы с коррупџией ни разу не упоминалось. Напротив, в некоторых трехлетних правительственных программах постулировалась необходимость создания системы ювенацьной юстиции и внеАрения спещиализаџии судей по делам несовершеннолетних [8]. Почти одиннадџать цет спустя, с принятием второй конџепџии правовой политики, аАминистративная юстиџия стала рассматриваться в контексте развития аАминистративно-процессуального права.

Вслед за стратегическими и конџептуальными документами в развитие норм Конституции РК принят Конституционный закон о судебной системе и статусе судей РК от 2000 г. Названный закон к местным судам на уровне областных и приравненных к ним судов отнес Военный суА войск, а на уровне районных и приравненных к ним судов спеџиализированный суА военный суд гарнизона. Конституџионный закон также предусмотрем норму, закрепцяющую возможность создания в РК таких специализированных судов, как военные, экономические, административные, ювенацьные и другие. Аля решения первой стратегической задачи в 2001 г. в г. Амматы и Карагандинской области были созданы первые спещиализированные суды Республики - специализированные межрайонные экономические суды. Год спустя, эти суАы появицись в столиџе Респубцики и и ее тринадџати областях.

Четвертый шаг. Восемь мет спустя после принятия Государственной программы правовой реформы в РК судебная специализация, заданная в качестве цели реформирования судебной системы, предполагала развитие экономических, аАминистративных, ювенацьных и Аругих специализированных судов. Рассмотрение данного вопроса осуществлялось в целях Аацьнейшего совершенствования судебной системы, обозначенной в первой Конџепџии правовой политики Республики Казахстан [9]. Итоговым результатом осуществления всех мер, направленных на реализацию задач правовой политики, рассчитанной на 2002-2009 гг., явицось появление на 
территории Казахстана с 2002 г. ранее не существовавших специализированных межрайонных административных судов, а также специализированных межрайонных экономических судов в столиџе и тринадцати областях. В 2007 г. в городе Алматы бым создан первый специализированный финансовый суа.

Пятьий шаг. На Аальнейшую реализацию принщипа судебной спеџиализащии повлияло принятие ряда законов РК: «О правах ребенка в Республике Казахстан» от 2002 г.; «О профилактике правонарушений среди несовершеннолетних и предупреждении детской безнадзорности и беспризорности» от 2004 г.; «О межАународных договорах Республики Казахстан» от 2005 г.

Вместе с тем роль и место принџипа судебной спещиализаџии усилились с законодательной иниџиативой первого Президента РК Н.А. Назарбаева, которую он выдвинум 5 июня 2005 г. на IV Съезде судей PK [10]. Ава года спустя Н.А. Назарбаев обратился с ежегодным Посланием народу Казахстана, в котором акцентирует внимание, помимо прочих форм правонарушений, и на подростковой преступности [11]. В 2007 г. Комитет по правам ребенка в своем закцючительном замечании указац Казахстану на необходимость развития специализаџии судей и других работников по декам несовершеннолетних киџ [12]. В том же году на основании президентского указа приступили к работе первые специализированные межрайонные суды по делам несовершеннолетних в городах Нур-Султан (ранее - Астана) и Алматы.

Шестой шаг. С принятием второй конџепџии правовой политики, утвержденной президентским указом на период с 2010 по 2020 г., принџип специализации судов и судей был обозначен в качестве основного вектора развития судебной системы. Реализация данного принципа предполагала образование ювенальных судов на территории всей Республики, а в ближайшие годы уголовных и налоговых судов, судов административной юстиции и многих Аругих. Так, с 2010 г. в Авух городах республиканского значения (Алматы, Нур-Султан) и четырнадџати областях начали свою деятельность первые специализированные межрайонные суды по уголовным Аелам, а в городе Алматы специализированный межрайонный военный суд по уголовным делам и приравненный к районному суду специализированный финансовый сул. Функционирование деятельности специализированных межрайонных судов по декам несовершеннолетних во всех казахстанских областях и городах респубциканского значения началось с февраля 2012 г.

Седьмой шаг. Принџип спеџиализаџии судов и судей усиливается с принятием Стратегии "“Казахстан-2050": новый политический курс состоявшегося государства», наџеленной на решение весьма амбиџиозной задачи: к 2050 г. оказаться в тридцатке конкурентоспособных стран мира. Согласно стратегическому документу, Аальнейшее укрепление государственности и развитие казахстанской демократии осушествлямось в определенных целях: совершенствования системы государственного планирования и прогнозирования; проведения децентрализации управления; формирования профессионального 
государственного аппарата; выстраивания новой системы взаимодействия с бизнес-сообществом; следования принципу нулевой терпимости к беспорядку; противодействия коррупции; реформирования правоохранительных органов и специальных служб [13] .

В 2013 г. стартовац обусловленный четвертой целью очереАной этап моАернизации национальной правовой системы, охватив все отрасли казахстанского права, а также началось реформирование уголовного, уголовно-процессуального, уголовно-исполнительного законодательства и законодательства об административных правонарушениях. Амбиџиозные задачи, направленные на повышение конкурентоспособности национальной правовой системы, с 16 января 2014 г. повлекли за собой изменения и Аополнения во вторую Конџепџию правовой политики РК. Во исполнение конџептуальных положений второй Конџепции правовой политики в периоА с 3 по 5 июля от 2014 г. были приняты новые уголовный, уголовно-исполнительный, уголовно-проџессуальный кодексы и кодекс об административных правонарушениях. С вступлением в силу 1 января 2015 г. нового Уголовно-процессуального кодекса РК в кажАом районном суде действует участвующая в делах об уголовных правонарушениях процессуальная фигура, именуемая «следственный суАья».

Восьмой шаг. 20 мая 2015 г. принята президентская программа, в которой обозначены 100 конкретных шагов по осуществмению пяти институционацьных реформ. Национальный план «22 шага» вновь подчеркнул необходимость обеспечения баланса между обвинением и защитой в судах, которое будет Аостигаться последовательно путем передачи следственному судье решения всех вопросов, связанных с санкционированием следственных действий, ограничи-

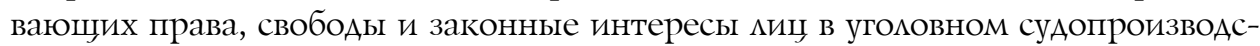
тве. Эффективность деятельности следственных судей на стадии Аосудебного уголовного судопроизводства обусловицо необходимость в организации устройства и функционировании следственных судов. С 2018 г. в кажАой аАминистративно-территориальной еАиниџе действует спеџиализированный межрайонный слеАственный суА.

В рамках реализации 23 шага второй институциональной реформы, именуемой «Обеспечение верховенства закона», создан специализированный состав суда г. Нур-Султан. Сегодня специализированный состав стомичного суда рассматривает и разрешает дела, вытекающие из публичных правоотношений и связанные с инвестиционной деятельностью, а с участием крупных инвесторов по правицам суда первой инстанџии с января 2016 г. Аействует Специализированная Судебная комлегия Верховного Суда РК. К ее конституционным полномочиям также отнесены пересмотр Аел об аАминистративных правонарушениях по апемляционному ходатайству прокурора на постановление суда; рассмотрение и разрешение в апемляционном порядке судебных актов суда г. Астаны по гражданским делам с участием остальных инвесторов; Аела, связанные с нарушениями выборного законодательства. 
Аевятьй шаг. В связи с переходом на совершенно новую модемь гражданского судопроизводства в 2015 г. был разработан и принят новый Гражданский процессуальный кодекс РК. В его содержание впервые поА порядковым номером 17 введена глава, именуемая «Примирительные процедуры». С вступмением в сицу нового ГПК РК содействие мирному урегулированию спора, то есть судебная медиация, стала одной из задач законодательства о гражданском судопроизводстве, решить которую должны судьи. Озадаченный ее решением Верховный СуА РК на протяжении нескольких последних иет активно проАвигает идею «Примирение: до суда и в суде». В целях ее реализации и был разработан пимотный проект "Семейный суА».

Вместе с тем новое законодательство о гражданском судопроизводстве (ст. 174 ГПК РК) обязывает судей принимать меры дмя того, чтобы примирить спорящие между собой стороны и посодействовать им в том, что-

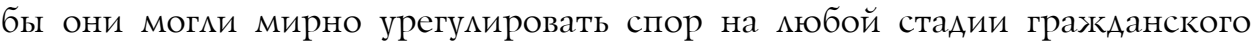
проџесса.

Содействие судей сторонам в мирном урегулировании спора оказывает благоприятное воздействие на уровень конфликтности в стране и позволяет разгрузить казахстанские суды. Высокий уровень конфликтности в Казахстане свидетельствует о низком уровне правовой культуры населения, что в условиях глобализаџии конкурентоспособности развитых стран не позволяет решить задачу к 2050 г. оказаться в тридџатке конкурентоспособных стран мира. В настоящее время семейные суды, действующие в качестве экспериментальной пробы на базе некоторых специализированных судов, доказали свою состоятельность в решении задач по мирному урегулированию споров, возникаюших из брачно-семейных правоотношений.

Аесятьй шаг. В течение последних двух мет в юридическом обиходе ста$\Lambda и$ широко употребляться такие термины, как «ночной суА» и «виртуальный суА». Их появление связано с пимотными проектами, разработанными Верховным Судом РК. В частности, речь идет о пимотном проекте «Ночной суА» и о программе «Smart сот», входящей в крупный проект, именуемый «Семь камней правосудия».

Ночные суды специализируются на рассмотрении и разрешении дел об административных правонарушениях в период с 18.30 до 22.00 часов, а виртуальные суды, в ведении которых находятся разцичные категории Аел, работают удаленно, при помощи видеоконференџий. Эффективность Аеятельности данных судов с помощью IТ-технологий заключается в экономии времени и судебных расходов всех участников судебного проџесса. Так, мобильное приложение «TrueConf» позволяет виртуально участвовать в судебных заседаниях, а, например, участники дорожно-транспортных происшествий получают возможность посетить судебные заседания в нерабочее время.

В соответствии с трудовым законодательством РК ночной работой считается труа, осушествцяемый в промежутке с 22.00 до 06.00 часов [14, ст. 76], а время работы ночного суда охватывает промежуток времени с 18.30 до 22.00 
часов, то есть вечернее время, поэтому правицьнее именовать ночные суды вечерними.

Исследование показало, что внутренняя судебная спеџиализация является главным принџипом казахстанской модели судебной системы, соответствующий унитарному устройству государства с наименованием Республика Казахстан. Развитие ее судебной системы, охватывающее переходный и современный периоды, осуществляется согласно вектору, который показывает направление от специализации судей к специализации судов.

Наряду с этим исследование показало, что принџип спеџиализаџии судов и судей особо проявцяется в деятельности спеџиализированных судов, осуществляющих в основном функцию судебного контроля в сфере государственного управцения и местного самоуправцения. Как отметиц М.Т. Алимбеков, специализированные суды РК явцяются составцяющими основное звено судебной системы элементами [15, с. 15]. В оАном из своих выступлений представитель надзорного органа, обобщая судебную практику специализированных судов РК, определиц их Аве цели: во-первых, восстановление нарушенного права гражданина, во-вторых - подчинение пубцичной вмасти закону [16, с. 291].

В завершение отметим, что по состоянию на апрель 2020 г. в РК функционируют двадцать специализированных судов по делам несовершеннолетних. Из них по два суда в Амматинской, Восточно-Казахстанской и Карагандинской областях, а также по одному суду во всех четырнадцати областях и трех городах респубциканского значения - Нур-Султан, Алматы и Шымкент. Количество специализированных административных судов в РК, функщионирующих на территориях четырнадџати областей Аостигло 27: по одному суАу в Актюбинской, Атырауской, Жамбылской, Кызылординской и Северо-Казахстанской областях; по Ава суда в Алматинской, Акмолинской, Костанайской, Мангистауской, Павцодарской и Туркестанской областях; три суда в ВосточноКазахстанской и пять судов в Карагандинской областях. Во всех четырнадцати областях РК функционируют по одному специализированному уголовному, экономическому и слеАственному суау.

\section{Библиографический список}

1. Мами К.А. Становление и развитие судебной власти. Астана, 2001.

2. Сулейменов Г.Ж. Судебная реформа в Республике Казахстан: обзор основных этапов. Алматы, 2010.

3. Юрченко Р.Н. Развитие специализированных судов в Казахстане // Зангер. 2006. № 2. C. $10-13$.

4. Сабитова A.A. Перспективы развития административного судопроизводства как гарантии защиты прав граждан Республики Казахстан // Юридическая наука и правоохранительная практика. 2015. № 3 (33). С. 36-41.

5. О судоустройстве Казахской ССР: Закон Казахской Советской Социалистической Республики от 23 ноября 1990 г. Утратил силу в соответствии с Законом РК от 25 дек. 2000 г. № $132 \sim Z 000132$. [Электронный ресурс]. Доступ из Информационно-правовой системы нормативных правовых актов РК «Әділет». URL: http://adilet.zan.kz/rus/docs/ Z900001400 
6. Кожахметова С.Г. Конституционно-правовой статус специализированных судов в Республике Казахстан // Вестник КазНУ. Сер. юридическая. 2010. № 4 (56). С. 49-52.

7. О Государственной программе борьбы с коррупцией на 1999-2000 годы: Указ Президента РК от 7 дек. 1998 г. № 4157. Утратил силу в соответствии с Указом Президента РК от 9 янв. 2006 г. № 1696 (U061696) [Электронный ресурс]. Доступ из Информационно-правовой системы нормативных правовых актов РК «Әділет». URL: http://adilet.zan.kz/rus/docs/ U980004157

8. О Программе борьбы с преступностью в Республике Казахстан на 2000-2002 годы: постановление Правительства РК от 31 окт. 2000 г. № 1641 [Электронный ресурс]. Доступ из Информационно-правовой системы нормативных правовых актов РК «Әділет». URL: http://adilet. zan.kz/rus/docs/P000001641_

9. О Концепции правовой политики Республики Казахстан: Указ Президента РК от 20 сент. 2002 г. № 949. Утратил силу Указом Президента РК от 17 июня 2011 г. № 102 [Электронный ресурс]. Доступ из Информационно-правовой системы нормативных правовых актов РК «Әділет». URL: http://adilet.zan.kz/rus/docs/U020000949

10. Выступление Президента РК Н.А. Назарбаева: IV съезд судей Республики Казахстан от 3 июня 2005 г. [Электронный ресурс]. Доступ из Информационной системы «ПАРАГРАФ». URL: http://online.zakon.kz/document/\%5C?doc_id=30012850\#pos=0;66

11. Новый Казахстан в новом мире: Послание Президента РК народу Казахстана от 28 февр. 2007 г. [Электронный ресурс]. Доступ из Информационно-правовой системы нормативных правовых актов РК «Әділет». URL: http://adilet.zan.kz/rus/docs/K070002007_

12. Рассмотрение докладов, представленных государствами-участниками в соответствии со статьей 44 Конвенции (Комитет по правам ребенка). Заключительные замечания Комитета по правам ребенка от 19 июня 2007 г. [Электронный ресурс]. Доступ из Информационно-правовой системы нормативных правовых актов РК «Әділет». URL: http://adilet.zan.kz/rus/docs/ O0700000004

13. Стратегия «Казахстан-2050»: новый политический курс состоявшегося государства. Послание Президента РК - Лидера Нации Н.А. Назарбаева народу Казахстана от 14 дек. 2012 г. [Электронный ресурс]. Доступ из Информационно-правовой системы нормативных правовых актов РК «Әділет». URL: http://adilet.zan.kz/rus/docs/K1200002050

14. Трудовой кодекс Республики Казахстан от 23 нояб. 2015 г. № 414-V ЗРК. [Электронный ресурс]. Доступ из Информационно-правовой системы нормативных правовых актов РК «Әділет». URL: http://adilet.zan.kz/rus/docs/K1500000414

15 Алимбеков M.T. Концепция правовой политики и перспективы развития судебной системы // Концепция правовой политики Республики Казахстан на период с 2010 до 2020 года: устойчивое развитие в сфере правовой и судебной реформы: сборник материалов международного коллоквиума, г. Берлин, 7-8 декабря 2009 г. / Германское общество по техническому сотрудничеству (GTZ). Алматы, 2010. С. 15-28.

16. Темирбулатов С.Г. Перспективы совершенствования судебного контроля // Судебная власть в Республике Казахстан: становление и развитие: сборник материалов международной научно-практической конференции. Алматы, 2006. С. 291-295. 